Зоја С. Карановић ${ }^{1}$

https://doi.org/10.46630/phm.13.2021.34

Универзитет у Новом Саду

Филозофски факултет

Департман за српску књижевност

\title{
ЗБИРАЈТЕ СЕ МОМЕ И ДЕВОЈКЕ: СРПСКИ СВАДБЕНИ ОБИЧАЈИ ВЕЗАНИ ЗА ЗБОРЊАК - ТЕРЕНСКА ИСТРАЖИВАҢА У БЕЛОМ ТИМОКУ
}

Нашим казивачицама

Предмет истраживања у овом раду представљају сегменти свадбених обичаја у Белом Тимоку који се везују за обредне и магијске радње, као и песме које су певане око главног свадбеног хлеба који се на истраживаном терену назива зборњак/зборник, у суседним областима и шире, на српском терену, познат је и под називом саборник, саборюак, соборғак. Ови називи одговарају поменутом ритуалном објекту и његовим функцијама, будући да се током свадбе око зборњака, вршећи различите радње, окупљају чланови заједнице који у њој учествују. Свадба у Тимоку зборњаком почиње, кад га у петак меси комшиница коју домаћица позива да то учини, а завршава се, односно „растура“ ломљењем зборњака и у кувањем попаре од тог хлеба, коју онда кусају прво младенци, а затим и остали присутни млађи чланови заједнице, момци и девојке. У основи главна функција овог ритуалног хлеба је интегративна - радњама око њега потврђује се заједништво групе, које је за премодерног човека традиционлне културе услов опстанка, што се у раду и показује.

Къучне речи: теренски рад, Бели Тимок, свадба, обред, зборњак, кићење зборњака, певање зборњаку, плаћање зборњака, кићење сватова цвећем са зборњака, ломљење зборњака

Ауторка овог рада боравила је, заједно са Весном Ђукић, на терену у делу Тимочке Крајине, у селима око Белог Тимока 2 , у неколико 1 zojanko@stcable.net

2 Теренска истраживања обављана су у селима: Боровац, Бучје, Валевац, Врбица, Витковац, Дебелица, Дреновац, Јаковац, Јелашница, Кожељ, Мариновац, Мали Извор, Ново Корито, Ошљане, Петруша, Потркање, Равна, Селачко, Трновац. 
наврата 1997. и 1998, кад је забележено преко 250 српских народних песама, с подацима о контексту, односно месту, времену и начину њиховог извођења, као и извођачима и осталим пропратним елементима (кад је то било могућно). И ова грађа припрема се за штампу. Касније, 2014, 2015. и 2016, ауторка је радила на истом терену с групом колега и студената чије истраживање је организовала и предводила. Намера је тада била да се, поред осталог, провере већ сачињени записи и, евентуално, пронађу нове још увек живе песме. ${ }^{3}$ Показало се, међутим, да већина ранијих казивачица више није међу нама ${ }^{4}$, док се оне с којима су разговори у новије време вођени углавном нису сећале песама, мада су и даље памтиле фрагменте некадашњих обреда у оквиру којих су песме извођене. ${ }^{5}$

Предмет истраживања у овом раду представљају сегменти свадбених обичаја у Тимоку који се везују за обредне и магијске радње око главног свадбеног хлеба који се на истраживаном терену назива зборњак, односно у песми зборник (како су га именовале и наше казивачице $)^{6}$, око којег се, током свадбе, окупљају различити чланови заједнице који у њој учествују.

На основу теренске грађе и неколиких описа ритуала из суседних области у раду је прво, на основи расположиве грађе, сачињена својеврсна идеалтипска (ре)конструкција припадајућих обреда ${ }^{7}$, посматраних као своје врсте културолошки текст, а који укључује елементе који припадају одговарајућим кодовима (акционалном, предметном, вербалном, персоналном, локативном, темпоралном, музичком, ликовном ${ }^{8}$ ),

3 Напомињем да се рад на терену одвијао без финансијске потпоре било које државне институције или невладине организације, као и без претходне припреме везане за сондирање терена и у вези с тим помоћи локалних власти. Рад је обављан методом случајног одабира саговорника. Разговори су у првом наврату снимани касетофоном, касније диктафоном, кад је било могуће, и ти снимци су у поседу истраживача. Разговори су иначе вођени уз пуну усмену сагласност казивача, на чему им захваљујемо.

4 Нека почивају у миру.

5 Свим нашим живим казивачицама овога пута топло захваљујем. Такође захваљујем колегиницама и студентима на уложеном труду и оживљавању сећања казивача.

6 Зборник или зборњак је „обредни, свадбени хлеб који окићен стоји на столу испред младенаца за време свечаног ручка (STEPANOVIĆ 2015: 19). Под овим називом познат je, на пример, ускршњи хлеб у Подравини (MESARIĆ и MATJUŠKO 2013: 150); овај хлеб познат је и под називом саборник, саборюак, соборюак У Нишави се зове соборњак (MIHAILOVIĆ 1971: 91-93), у Срему саборник (MARKOVIĆ 2017: 117)...

7 Реконструкција је сачињена на основу појединачних описа из теренске грађе и литературе.

8 Акционални код подразумева редослед одређених радњи, у којем се користе различити предмети који имају симболичка својства, вербални код обухвата пропратне текстове који се том приликом изводе, извођачи припадају персоналном коду, док се простор у којем се радње одржавају везује за локативни код, време одржавања ритуала везује се за темпорални код, музички код је певање, или интрументална пратња, док ли- 
при чему су сви они семиотички маркирани и у односу на своје природне прототипове различити и носе симболичка значења (TOLSTOJ 1995: 141-143). И овде су посматрани, пре свега, у међусобном преплитању, пошто их је углавном немогуће раздвојити, осим за потребе схематског приказа, будући да се одвијају не само сукцесивно, већ често и истовремено.

Познато је да је зборњак хлеб који се о свадби први умеси, у петак (меси га жена из суседства, коју домаћица за ту намену позове) и тиме он „започиње свадбу“; кад се зборњак испече ставља се на софру, а увече девојке (певице) долазе у момкову кућу ките га цвећем, певајући му, истовремено „намењујући сваки цвет овоме или ономе момку“ за којег су заинтересоване, док младожења из шљивара донесе дрвце са три ракље, на које се набоду три вараклисане јабуке (STANOJEVIĆ 1929: 43). ${ }^{9} \mathrm{O}$ девојкама које су китиле зборник овако је сведочила је баба Зора из Селачка, која је и сама била певица: „Девојке певице, било их је четири са момкове стране, долазе уочи свадбе код момка на вечеру“.10 Такође је, по казивању Божике Живковић из Витковца, било обавезно да старојка, кад увече дође дарује зборњак. Зборњак, затим, стоји испред младенаца за време ручка (SAVIĆ GRUJIĆ 2010: 257) ${ }^{11}$, све до свршетка свадбе. У току свадбе се, по сведочанству казивачице из Витковца, „цвећем са зборњака ките сватови“12 (Божика Живковић; KARANOVIĆ 2015: 381). У литератури је такође потврђено да зборњак за време свадбе стоји на софри испред младенаца, све до њеног свршетка. А на крају, кад се испрати стари сват, зборњак се издроби и од њега сачини попара, коју најпре кусају младенци, а после њих присутни девојке и момци (STANOJEVIĆ 1929: 77). И у грађи из Алексиначког Поморавља потврђено је да свадба траје све док се зборњак (тамо саборник) не изломи и не поједе (ANTONIJEVIĆ 1971: 144-146). А ово је посведочено и на терену:

Кад се увече растура свадба, ломи се зборњак и од зборњака се прави

ковни код подразумева различите визуализације предмета и учесника (TOLSTOJ 1995: 141).

9 Девојачки зборник, који је у средини проваљен, мешен је у њеној кући (STANOJEVIĆ 1929: 52).

10 Певице још у 19. веку у оквиру свог описа свадбе у Тимоку на сличан начин помиње Милан Ђ. Милићевић (1876: 866).

11 Варијантно, у Алексиначком Поморављу „саборник, се меси уочи свадбе у младожењиној кући, меси га девојка чији су родитељи живи и који се, кад падне мрак, износи на дрвљаник (место где бораве душе), где се у њега забије ракљасто дрво са три гране, на чије врхове се закачи по једна црвена јабука (у новије време узима се читаво стабло са тридесет и више гранчица и на сваку се ставља по једна јабука, па се, тако окићен, врати у кућу и стави у чело софре ради даривања“ (ANTONIJEVIĆ 1971: 146).

12 Постоји и запис о томе да свака девојка свој цвет намењује неком момку (STANOJEVIĆ 1929 II: 43). 
попара и млада први пут једе храну из младожењине куће. Ту попару једу младеници и гледају ко ће коме да избије кашику из руке. Онај који је избије из руке, биће газда у кући. И ми смо направили попару. Ал ме он удари кашиком. Излете! Не даде ми да једем (Божика Живковић, Витковац).

Основни интегративни објекат (предмет) о којем је овде реч, и око којег се окупљају сватови, у Тимоку је, дакле, главни обредни хлеб који се, сходно поменутој функцији и назива зборњак, а затим и флорални аранжмани на њему. У његовом прављењу учествује домаћица која зове комшиницу месиљу, да га направи, а ките га певице, намењујући цветове момку у којег су се загледале (персонални, предметни, ликовни код... $\left.{ }^{13}\right)$. Доминантну улогу у овом обреду, у вези са основном храном и биљним реквизитима, дакле, имају старији и млађи женски чланови заједнице којима припадају радње око прављења и украшавања хлеба, док се посредно и пројектовано укључују и момци којима девојке намењују своје цветове (такође персонални, акционални, предментни, ликовни код...). Затим, кад у суботу у младожењину кућу дође стари сват, он је обавезан да дарује зборњак ${ }^{14}$, чиме се у обреде око њега укључује и један од најзначајних такође мушких часника. О свадби се, затим, цвећем са зборњака ките сватови (предметни, акционални, персонални, ликовни... код), чиме се број учесника у ритуалима око зборњака даље шири. И истовремено се одвија процес везивања различитих припадника групе и демонстрира заједништво на различитим нивоима. ${ }^{15}$ На крају, кад се свадба растура, од зборњака се прави попара (акционалани и предметни, персонални кодови се преплићу). И у оквиру ове радње ритуални објекат чија је улога у току свадбе интегративна, трансформише се у наизгледно супротни - растурни, тј. завршни. Зборњаком, дакле, свадба започиње и њиме се завршава. А попара коју на крају једу млада и младожења, а затим присутни момци и девојке, антиципира заједништво на другом нивоу и у друго време - у наставку.

Док су китиле зборњак, девојке су певале, у једној песми дословно пратећи извођене аналогне радње и тиме „репродукујући“ акционалну страну ритуала ${ }^{16}$, апострофирајући прво разлоге окупљања, а на крају

13 Свакако и локативни и темпорални код, будући да је хронотоп такође утврђен и кодиран - све се одвија у младожењиној кући: мешење, кићење, даривање...

14 О важности даривања и размене дарова у премодерном свету које је било засновано на принципу узајамности и заједништва: (MOS 1982: 7-222); о важности дара приликом склапања брака у српској свадби види: KARANOVIĆ 1992: 116 -149.

15 Мисли се на чланове породице (биолошке и социјалне сроднике), затим на несродничке чланове заједнице - мушки и женски, стари и млади... Неопходно је да сви, на овај или онај начин, учествују у свадби.

16 Општење у обреду свадбе иначе се остварује помоћу свадбених песама, одговарау 
кићење часника, које је такође део садржине песме, овако:

Збирајте се, збирајте се, моме и дево...

Еј, девојко,

Збирајте се, моме и девојке.

Да ћитимо пребела зборника

Од босиљка, драго, крстатога,

Од стратора, драго, крстатога

И од смиља, драго, крстатога.

Да ћитимо свекра и свекрву,

Да ћитимо кума и старојку.

(Милица Петковић, Врбища)

Ова песма, иначе јединствен запис своје врсте, суштински је садржином повезана с одговарајућим ритуалним поступцима с којима је у корелацији, и које на својеврстан начин коментарише (место, време, радње, актери ..., у преплитањ $\left.{ }^{17}\right)$. У њој је, пре свега, евидентно дублирање акционалног и вербално-поетског кода, односно у овом сегменту постоји тесна веза обредне радње и поезије. ${ }^{18}$ И њена природа је таква да се у тренутку извођења не може успоставити граница између акције и вербализације, пре би се рекло да једна другу сустижу у својеврсној појавности обредног синкретизма, релативизујући и проток времена који у ритуалу иначе не одговара његовом свакодневном поимању. ${ }^{19}$

Саму песму отвара ултимативно обраћање невидљивог казивача девојкама (императив плус вокатив), којим се (заповешћу) настоји постићи сигурност деловања ${ }^{20}$, из прва два стиха, које се у трећем, парафразиразирајући увод у окупљање девојака, демистификује као самообраћање (важност повезивања и заједничког деловања), одмах затим откривајући и намеру девојака - да оките зборник, што је обредна радња о којој се и регионалној у литератури говори на више страна (GRBIĆ 1909: 157; ANTONIJEVIĆ 1971: 145) 21, а коју у Тимоку описује Маринко

јућих текстова и ритуалних радњи (GURA 2006: 273), као и осталих пратећих елемената (TOLSTOJ 1995: 141-143).

17 С истовременим присуством осталих кодова - темпорални и локативни, ликовни...

18 Општење у овом обреду иначе се остварује помоћу свадбених текстова, односно песама и ритуалних радњи (GURA 2006: 273), што није увек непосредно видљиво и утолико је овде важније.

19 Обредно време има особине другачије од уобичајеног тока времена. Оно може бити развучено или спресовано (TARNER 1986: 41-43).

20 Овај облик, како је запазио још Јакобсон, представља прастару форму комуникације (1966: 292) и потврђује архаичност исказа у песми.

21 Види, на пример, стихове: „Колач га размесити, / С мотику га расплескајте. / Колач ra закитите, / Со две китке босиљкове / Босиљкове страторове“ (ĐORĐEVIĆ 1934: 59). 
Станојевић још почетком прошлог века (STANOJEVIĆ 1929: 43). ${ }^{22}$

У првим стиховима, понављањима кључних речи („збирајте се“ и „моме и девојке“), у формули позива на вршњачко окупљање 23 (ритуалних помоћника), фокусира се на важност заједничког деловања. ${ }^{24}$ Затим се апострофирају разлози сабирања девојака, стихом: „Да ћитимо пребела зборника“, којим се открива објекат, на којем се обављају кључне радње (кићења). И уједно се скреће пажња на његову важност у свадби. A, сходно томе, и на квалитет хлеба као најсакралнијег вида суштинске хране, симбола добитка, изобиља и благостања (TOPORKOV 2001: 562; GERBRAN и ŠEVALIJE 2004: 274; JOVANOVIĆ 2010: 97-106), којим се међусобно и стадијално повезују различити чланови заједнице, а који на овај или онај начин учествују у стварности ритуала (домаћица, месиља, девојке). У овом стиху даље се истиче квалитет хлеба, формулативним

22 Сам аутор, без обзира што је грађа публикована 1929. каже да она датира из времена од 1900. до 1905. године (STANOJEVIĆ 1929: 23).

23 Поменути формулативни исказ јавља се и у сватовским песмама, у обраћању момцима у стиху: „Збирајте се младожењски момци (JELESIĆ http://www.izvornepesme.org/ rec/30/218_30_1.mp3); омиљен је у седенћарским, као: „Збирајте се, друшће/моме, на седенћу“ (STANOJEVIĆ 1903: 97; MANOJLOVIĆ 1953: бр. 80a; JOCIĆ, JOCIĆ и др. 1979: бр. 184; ĐORĐEVIĆ и ZLATANOVIĆ 1990: бр. 190), који су у литертури препознати као императивни формулативни искази поменутих песама: „збирајте се“, „скупљјте се“, „сабирајте се“ (ŠORAK 2013: 214). А јавља се и у песмама другачије садржине, у жетелачкој или песми љубавне садржине (RAJKOVIĆ KOŽELJAC 1978: бр. 50 и бр. 220).

Под појмом формуле иначе се подразумевају устаљена и наслеђена средства изражавања, која се у науци именују и дефинишу разнолико, при чему се овде користити дефиниција која каже да је формула основно градивно језгро усмене песничке традиције (како то за епику каже Алберт Лорд), односно представља (речи) и скупине речи које се редовно користе „под истим метричким условима да изрази[е] дату основну идеју“ (Parry), док се под формулативним изразом означава „стих или полустих конструисан по обрасцу формула“" (LORD 1990: 21). Уз то, отвореност, динамичност и помичност формуле које Мирјана Детелић уочава на почетку и на крају епске структуре (1996: 33 и 51), такође представљају њене карактеристике. Треба такође додати да формула није својствена само епици - и лирика почива на поетици формула. И у том смислу формула је: средиште семантичке гравитације, на које се одлажу духовне вредности читавих епоха (Формула - это иентр семантической гравитации, на который оседают духовные ценности цельх эпох (MALJCEV 1989: 87)), што је у овом примеру и видљиво. И, сходно томе, поетика текста и поетика традиције садрже дубинска значења (текст активно комуницира с традицијом) која се сучељавају у формули (MALJCEV 1989: 85). Или: „Формула - то је облик текста, и компонента његовог садржаја, и „кретања“ ка садржају, пут од „облика“ ка „смислу““ (Формула - это и форма текста, и компонент его содержания, и способ „движения“ $к$ содержанию, путь от „бормы“ $к$ „смыслу“ (MALJCEV 1989: 54).

24 У селима око Бољевца том приликом се певало о потреби окупљања свих сватова, овако: „На збор, на збор, мало и велико/ Да зберемо кума и старојка/ Да зберемо кићене сватове“ (GRBIĆ 1909: 157). 
атрибутом пребели (у говору редак суперлативни облик придева бео ${ }^{25}$ ), који је у усменој песничкој традицији фреквентан, високо вреднован и везује за обредну храну сачињену од брашна ${ }^{26}$, истичући јој особину посебног квалитета ${ }^{27}$ - овај вишеслојно кодиран придев иначе припада и другим изузетним артефактима српске културе. ${ }^{28}$

У стиховима који следе, затим, описано је кићење зборника, чему припада централно место у песми. И то се постиже набрајањем и уједно нагомилавањем врста цвећа, којима је зборник иначе украшаван у обреду и у песми, у облику својеврсних паралелизама, стиховима:

Да ћитимо пребела зборника.

Од босиљка, драго, крстатога,

Од стратора, драго, крстатога

И од смиља, драго, крстатога.

Паралелизми и набрајања иначе се налазе у структури и семантици обреда и од давнина служе повезивању по сличности (JAKOBSON 1966: 80), што је овде евидентно, а што се очитује и истоврсном природом коришћених граматичких и синтаксичких облика, као и аналогном функционалношћу биљака у српској култури, познатих по заштитним моћима и магијским својствима.

Биљке којима је кићен зборник у песми (и у стварности), нижу се, дакле, у паралелизмима, поступно и стадијално симулирајући појединачне радње забадања њихових цветова у хлеб, будући да је било неопходно да свака девојка на њега дода своју биљку. Високо је даље овде мотивисано и коришћење генитивног облика (истовремено партитивног и квалитативног) за поменуте биљке, на почетку сваког од три стиха овако: „од босиљка“, „од стратора“, „од смиља“ (уместо уобичаје25 Овде „делује метонимијски принцип преноса квалификација по моделу производ направљен од белог материјала (брашна)“ (STANIĆ 2012: 291).

26 Види нпр: пребела погача, пребели колачи, пребели симити... (STANIĆ 2012: 281296). Овакви хлебови се високо вреднују и у контрасту су црним хлебом, који у култури несташице такође може имати позитивна својства, као: „Бољи је и црн колач него празна торба“, или са хлебом који није сачињен од пшенице, већ је, на пример, хлеб од јечма: јечменица, јечмени хлеб, или кукуруза, кукурузница, уз реч проха, са изреком: „Жива жељо, кукурузна пројо“, која негативно вреднује кукурузни хлеб, а бележи је Вуков речник. Недељко Богдановић говори о високом вредновању белог хлеба у култури; био је редак и правио се у посебним приликама (BOGDANOVIĆ 2010: 249-254).

27 Хроматски код бео у традицијској култури је синоним за позитивно вредновање (POPOVIĆ 2001: 14-31), чиме и овде садржина песме улази у активни однос с традицијом (дијалог текста и традиције иначе је у лирици непрекидан и обавезан (в. MALJCEV 1989: 71).

28 Атрибут пребели стоји уз опис људског тела и делова тела, одеће и материјала од којег је одећа сачињена, света фауне и флоре (пшеница), различитих производа техничке природе, као хартија... 
ног инструментала), јер овим обликом упућује се на то да се овде ради о гранчицама издвојеним из целине, које девојке прилажу на обредни хлеб. „Цветне стихове“ међусобно даље повезује придев крстати, којим се они завршавају (епифора), односно којим се на крају атрибуира свака од три биљке и њеном облику се даје завршни смисао. И на овај начин апострофира се и појачава завршна реч чије је значење донекле замагљено. Будући, међутим, да се основни смисао овог придева изводи из именице крст, онај који на себи има знак крста (KARADŽIĆ 1852) ${ }^{29}$, може се претпоставити да је сваки цвет, пре него што је положен у хлеб, закрштаван ${ }^{30}$, како би се овим актом везао за свет културе ${ }^{31}$ и подигла му се моћ деловања, што је онда у песми маркирано овом атрибуцијом. ${ }^{32}$ Ни семантички потенцијали речи драго, која се понавља унутар сваког од „цветних стихова“, увек на истом месту, након цезуре, нису до краја дешифровани, па би овде могло да се ради о прилошкој усмерености на дату атрибуцију, у значењу драго крстатога, овако: „Од босиљка драго крстатога/Од стратора драго крстатога/..., мада је вероватније реч о вокативу придевске именице драго. Односно да девојка док кити зборник и намењује га неком момку, тог момка у мислима и дозива, па би стихови у писаном облику изгледали овако: „Од босиљка, драго, крстатога,/ Од стратора, драго, крстатога/ ..., што је својеврсна вербална репродукција оног што девојке током кићења чине. Оне намењују „сваки цвет овоме или ономе момку“, чија се наклоност магијским путем жели изазвати, у песми га уопштено помињући и дозивајући његову љубав, уметањем вокативског облика придевске именице у стихове фокусиране на биље. Присуство облика вокатива исте именице иначе потврђује и аналогни пример песме која се певала кад се вије венац, а много раније је публикована. И у њој је реч драго штампана међу зарезиима, односно у вокативу, овако:

29 О одговарајућим значењима речи крсташ и крстати види и RJAZU.

30 Познати су, на пример, микролокалитети, као крстати брес, који се односи на конкретно закрштено дрво, запис (ŽUGIĆ 2013:108-109).

31 Манипулација биљем је иначе сложен процес у којем се активирају различита знања која углавном припадају старијим женским особама, или још више демонском свету, вилама (ĐORĐEVIĆ 1953: 103-104; ĐORĐEVIĆ 1958: 573). „У нашој религији и митологији најчувеније биљарице јесу женски демони, виле. Оне се и рађају из биљака или из дрвећа, и живе у њима или око њих; чак и њихова егзистенција зависи, у највећој мери, од магичних биљака“ (ČAJKANOVIĆ 19946: 178). Познато је да је смиље вилинско цвеhe (ČAJKANOVIĆ 1994a: 189; GURA 2011: 126).

32 Ова атрибуција иначе не припада основи номинације поменутих биљака, мада је неке биљке у свом називу имају, као: Кристати копитғьак (Anemone hepatica), Крстата трава (Pastinaca sativa Psilvestris), Кристати слез (Abutilon; Avicennae), Кристапо игличе (Primula veris), Кристато јагличе (Primula veris), Кристато јегличе (Primula vetis). 
Вила Јана, драго, зелен венац,

Вила је га, па му говорила:

„Виј се венче, драго, довијај се,

Да те носи, драго, Давњан јунак,

Давњан јунак, драго, добра девојћа.“

(STANOJEVIĆ 1929: 46)

Уметањем поменуте придевске именице наведени стихови се обликују и проширују, од осмерца до развијенијег епског десетерца, који својом дужином и успоравањем исказа савршено одговара вишеструком мађијању, које је прво усмерено на хлеб, па на замишљене момке, а затим и на остале учеснике у свадби који ће, у пројектованој будућности, на овај или онај начин, са њим доћи у додир и преко њега се повезати, а самим тим и учврстити заједницу.

Саме, пак, биљке којима је зборањак кићен - босиљак (Ocimum basilicum), тратор/стратор (Amaranthus peniculatus) и смиље (Helichrysum arenarium), које у кићењу (и у песми) имају важну улогу, у традиционалној култури су иначе високо вредноване.

Босиљак је, тако, у култури Срба биљка над биљкама, света биљка прве врсте (С̌AJKANOVIĆ 1935: 3-10). А иначе је и важан реквизит заштите код прављења свадбених хлебова у Срба - замешује се у шарену свадбену проју, њиме су кићени и други свадбени колачи (С̌AJKANOVIĆ 1994a: 39-40) - а босиљком се ките и остали предмети и учесници у ритуалима око склапања брака - њиме се гата о удаји, млада младожењу гледа кроз босиљак, да би је волео и др. (С̌AJKANOVIĆ 1994a: 40-41). ${ }^{33}$ И зато му и у овом песничком низу припада првенство. И смиљу, чије су апотропејске моћи у предсвадбеној и свадбеној обредности код Срба такође снажне, припада у песми важно место. Смиље се и иначе често јавља у комбинацији с босиљком (С̌AJKANOVIĆ 1994a: 189; STEFANOVIĆ 2014: 63-70). Од њега је, такође, прављен свабени венац (GURA 1995: 322), кроз који девојка гледа момка, а и најважнија невестачка капа, сми ᄀљевац је од овог цвећа (С̌AJKANOVIĆ 1994a: 188-189). И трећа биљка која се у песми помиње, тратор, односно овде стратор, у предсвабеној и свадбеној ритуалности у Тимоку је такође имала важно место (STANOJEVIĆ 1929: 36, 42-43. 45-46, 48), иако му у класичној етнографској литератури не припада истакнута позиција, једва да га помиње Софрић (1912: 211). Треба такође додати да су босиљак, тратор/стратор и смиље редовно ко-

33 „Как универсальное охранительное и отгонное средство базилик использовался для украшения людей, животных, построек, предметов домашнего обихода, пищи и т. п. Для этого изготавливали венки, букетики, гирлянды, часто с другими растениями (...) или брали отдельные веточки, цветы“ (USAČEVA 1995: 131). О утемељености босиљка у хришћанској религији где је, између осталог, апотропеј прве врсте, али и медијатор између људи и божанске силе (RENKAS 2016: 41). 
ришћени за кићење ритуалних хлебова и осталих реквизита и учесника у сватовској пракси у Тимоку, о чему постоје сведочења још од почетка прошлог века (STANOJEVIĆ 1929: 36, 42-43), чиме је њихово присуство, захваљујући постојећим записма, посведочено у акционалној и вербалној димензији обреда које се међусобно допуњавају и објашњавају, што је овде и показано. А све заједно илуструје начин на који акционалне и вербалне манифестације обреда могу бити, и јесу, реплика стварности и у односу су корелације.

Важност поменутих флоралних реквизита, затим, подиже њихова даља магијска и заштитна намена, у завршним стиховима: „Да ћитимо свекра и свекрву/ Да ћитимо кума и старојку“. ${ }^{34}$ Цвећем са зборњака девојке о свадби иначе ките сватове, што је посведочила казивачица из Врбице, а потврдила песма. У њој се прво помиње свекар, па свекрва, а затим кум и старојко. И радњама које се том приликом изводе, дакле, повезују се чланови заједнице који су у крвном или социјалном сродству (али се везивање простире и на остале учеснике свадбе). А кроз овакав редослед међусобног везивања око зборњака, у песми је демонстрирана обредна хијерархија, али и хијерарихија учесника у социјалној структури. Па се може рећи да функиција појединих лица и предмета у свадби не зависи само од времена и места које заузимају у обреду, већ је она и обавезни рефлекс њиховог положаја у друштву и стога својеврсна „школа социјализације“ чланова заједнице.

На крају, како је забележено на терену и у литератури, кад се свадба растура ломи се и „зборњак и од зборњака се прави попара и млада први пут једе храну из младожењине куће. Ту попару једу младеници и гледају ко ће коме да избије кашику из руке.“ И управо у овој тачки се симболички укрштају прошло, потрошено време и, у првом заједничком јелу младенаца, нова (брачна) стварност која догађаје окреће према будућности...

Гледано у целини, дакле, будући да зборњаком почиње и завршава се свадба, те да он „у обреду јесте средишња тачка окупљања учесника свадбе за свадбеним столом“ (BOGDANOVIĆ 2010: 252), овде се прате неколике фазе ритуала које у целини представљају комплекснију структуру - поред акционалне и вербалне димензије, чине је и остали елементи - локативни, темпорални, мелодијски, предметни... Па је, у крајњем, свадбени обред особен текст својеврсних знаковних подсистема - кодова који долазе у различите међуодносе, при чему знакови једног поретка (у својеврсној динамици преплитања) замењују знакове другог низа (GURA 2006: 268-271). И то се догађа током читавог ритуала (али га 34 Редослед учесника у песмама које су директно повезане с ритуалиним поступцима усклађен је с одговарајућим радњама, и они се ређају по важности, што је и основа за обликовање градације. 
и надилази), показујући како су његове различите стране некада могле представљати неразлучиву целину ${ }^{35}$, односно како су шавови на којима су спојени акција и вербализација тако били повезивани да чине једно, односно да репрезентују заједништво - у ритуалу, али и изван њега. То се, наравно, углавном више не може пратити, јер различите димензије обредне стукртуре које су нам данас на располагању само су рефлекси некадашње целине и најчешће нису више у односу синонимије. Зато ће пре бити да они упућују на процес међусобног удаљавања, него приближавања и осветљавања целине (обреда и реалности) која нам пред очима ишчезава - у неповрат.

\section{Цитирана литература}

ANTONIJEVIĆ 1971: ANTONIJEVIĆ, Dragoslav. „Aleksinačko Pomoravlje“. Srpski etnografski zbornik, br. 83, Beograd: SANU, 1971. [orig.] Антонијевић, Драгослав. „Алексиначко Поморавље.“ Српски етнографски зборник, бр. 83, Београд: САНУ, 1971.

BOGDANOVIĆ 2010: BOGDANOVIĆ, Nedeljko. „Motivaciona osnova tvorbe reči u vezi sa hlebom“. Tradicionalna estetska kultura. Hleb. Prir. Dragan Žunić. Niš: Centar za naučna istraživanja SANU i Univerziteta u Nišu, 2010, 249254. [orig.] Богдановић, Недељко. „Мотивациона основа творбе речи у вези са хлебом“. Традиционална естетска култура. Хлеб. прир. Драган Жунић. Ниш: Центар за научна истраживања САНУ и Универзитета у Нишу, 2010, 249-254.

GERBRAN, ŠEVALIJE 2004: Gheerbrant, Alain и Chevalier, Jean. „Kolač“. Rečnik simbola. Novi Sad: Stilos, 2004, 274.

GRBIĆ 1909: GRBIĆ, Savatije. „Srpski narodni običaji iz Sreza Boljevačkog“. Srpski etnografski zbornik, knj. XIV, Beograd: SANU, 1909. [orig.] Грбић, Саватије. „Српски народни обичаји из Среза Бољевачког“. Српски етнографски зборник, књ. ХIV. Београд: САНУ, 1909.

GURA 1995: GURA, Aleksandar. „Venok svadbenji“. Slavjanske drevnosti. Etnolingvističeskij slovar v pjati tomah: Ur. N. I. Tolstogo. T. 1. Moskva: Institut slavnovedenija RAN, 1995, 321-325. [orig.] Гура, Александар. „Венок свадебный.“ Славянские древности. Этнолингвистический словарь в пяти томах: : ур. Н. И. Толстого, т. 1. Москва: Институт славноведения РАН: 1995, 321-325.

GURA 2006: GURA, Aleksandar. „Sotnošenije i vzaimodejstvie akcionalnogo i verbalnogo kodov svadbenogo obrjada“. Slavjanskij $i$ balkanskij folklor. Moskva: Indrik, 2006, 268-279. [orig.] Гура, Александар. „Соотношение и взаимодействие акционального и вербального кодов свадебного обряда.“ Славянский и балканский фольклор. Москва: Индрик, 2006, 268-279.

35 „Словесная программа ритуала и самый ритуал некогда могли представлять единое нерасчленненое целое“" (IVANOV 1976: 5). 
GURA 2011: GURA, Aleksandar. „Soroka“. Slavjanskie drevnosti. Etnolingvističeskij slovar v pjati tomah: T. 1.Ur.N. I. Tolstogo. Moskva: Institut slavnovedenija RAN, 1995, 125-128. [orig.] Гура, Александар. „Сорока“, Славянские древности. Этнолингвистический словарь в пяти томах, т. 1. Ур. Н. И. Толстого, Москва: Институт славноведения РАН, 125-128.

DETELIĆ 1996: DETELIĆ, Mirjana. Urok i nevesta, poetika epske formule. Beograd: SANU i Univerzitet u Kragujevcu, 1996. [orig.] Детелић, Мирјана. Урок и невеста, поетика епске формуле. Београд: САНУ и Универзитет у Крагујевцу, 1996.

ĐORĐEVIĆ 1934: ĐORĐEVIĆ, Vera. „O svatovskoj pogači u okolini Skoplja. Momkov kolač“. Glasnik etnografskog muzeja IX, 1934, 58-63. [orig.] Ђорђевић, Вера. „О сватовској погачи у околини Скопља. Момков колач.“ Гласник етнографског музеја IX, 1934, 58-63.

ĐORĐEVIĆ 1958: ĐORĐEVIĆ, Dragutin. „Život i običaji narodni u Leskovačkoj Moravi“. Srpski etnografski zbornik, knj. LXI, Beograd: SANU, 1953. [orig.] Ђорђевић Драгутин. „Живот и обичаји народни у Лесковачкој Морави“. Српски етнографски зборник, књ. LXX, Београд: САНУ, 1958.

ĐORĐEVIĆ 1953: ĐORĐEVIĆ, Tihomir. „Veštica i vila u našem narodnom verovanju i predanju“. Srpski etnografski zbornik LXI, Beograd: SANU, 1953. [orig.] Ђорђевић, Тихомир. „Вештица и вила у нашем народном веровању и предању“. Српски етнографски зборник LXI, Београд: САНУ,1953.

ŽUGIĆ 2013: ŽUGIĆ, Radmila. Mikrotoponomija gornjeg sliva Jablanice (semantičko-tvorbeni aspekt). Beograd: Institut za srpski jezik SANU, 2013. [orig.] Жугић, Радмила. Микротопонимија горњег слива Јабланице (семантичко-творбени аспект). Београд: Институт за српски језик CAHУ, 2013.

IVANOV 1976: IVANOV, Vjačeslav. Očerki po istorij semitiki v SSSR. Moskva: Nauka, 1976. [orig.] Иванов, Вячесла́в. Очерки по истории семитики в СССР. Москва: Наука, 1976.

JAKOBSON 1966: Jakobson, Roman. Lingvisitka i poetika, prev. D. Pervaz, T. Bekić, V. Vuletić, S. Marić, R. Bugarski: Nolit, Beograd, 1966.

JELISIĆ 2007: JELISIĆ R. R. (postavio i održava). Srpske izvorne pesme. Etnomuzikološki odsek Muzičke škole „Mokranjac“. Beograd (0.8 MB, mp3), Bujanovac. <http://www.izvornepesme.org/rec/30/218_30_1.mp3> [orig.] Јелесић Р. P. (поставио и одржава). Српске изворне песме. Етномузиколошки одсек Музичке школе „Мокрањац“: Београд (0.8 MB, mp3), Бујановац. $<$ http://www.izvornepesme.org/rec/30/218_30_1.mp3>

JOVANOVIĆ 2010: JOVANOVIĆ, Bojan. „Obedni o obredni hleb”. Tradicionalna estetska kultura. Hleb. Prir. Dragan Žunić. Niš: Centar za naučna istraživanja SANU i Univerziteta u Nišu, 97-106. [orig.] Јовановић, Бојан. „Обедни и обредни хлеб“. Традиционална естетска култура. Хлеб. Прир. Драган Жунић. Ниш: Центар за научна истраживања САНУ и Универзитета у Нишу, 97-106.

KARANOVIĆ 1992: KARANOVIĆ, Zoja. „Svadba i dar, ili dijalog koji traje“. Poetika dara i darivanja u jugoslovenskim književnostima. Ur. M. Radović. 
Sombor: Dometi, 1992, 116-149. [orig.] Карановић, Зоја. „Свадба и дар, или дијалог који траје“. Поетика дара и даривања у југословенским књижевностима, ур. М. Радовић. Сомбор: Домети, 1992, 116-149.

KARANOVIĆ 2015: KARANOVIĆ, Zoja. „S ljudima umiru pesme: beleške s terena u torlačkim selima oko Belog Timoka“. Savremena srpska folkloristika II. Ur. S. Đorđević, D. Lajić i dr. Beograd: UF Srbije - Institut za književnost, Beograd: UB „Svetozar Marković, 2015, 367-388. [orig.] Карановић, Зоја. „С људима умиру песме: белешке с терена у торлачким селима око Белог Тимока“. Савремена српска фолклористика II. Ур. С. Ђорђевић, Д. Лајић и др. Београд: УФ Србије-Институт за књижевност, Београд: УБ „Светозар Марковић“, 2015, 367-388.

LORD 1990: Lord, Albert B. Pevač priča I i II. Prev. S. Glišić, Beograd: Idea, 1990.

MALJCEV 1989: MALJCEV, Georgij Ivanovič. Tradicionalnie formuli ruskoj narodnoj neobrjadovoj liriki. Leningrad: Akademija nauk SSSR, Institut ruskoj literaturi, 1989. [orig.] Мальцев, Георгий Иванович. Традиционалньие формулы русской народной необредовой тирики. Ленинград: Академия наук СССР, Институт русской литетатры, 1989.

MARKOVIĆ 2017: MARKOVIĆ, Dušanka. Srpski svadbeni običaji u Vojvodini. Novi Sad: Muzej grada Novog Sada, 2017. [orig.] Марковић, Душанка Српски свадбени обичаји у Војводини. Нови Сад: Музеј града Новог Сада, 2017.

MESARIĆ, MATIJAŠKO 2013: Mesarić Marija i Matijaško, Nada. „Kultura prehrane u Podravini“. Podravski zbornik, br. 39, 2013, 149-163.

MILIĆEVIĆ 1876: MILIĆEVIĆ, Milan Đ. Kneževina Srbija. Beograd: Državna štamparija, 1876. [orig.] Милићевић, Милан Ђ. Кнежевина Србија. Београд: Државна штампарија, 1876.

MIHAILOVIĆ 1971: MIHAILOVIĆ, Sunčica. „Svadbeni običaji u Nišavi“. Glasnik etnografskog muzeja u Beogradu br. 74, 1971, 85-104. [orig.] Михаиловић, Сунчица. „Свадбени обичаји у Нишави“. Гласник етнограбског музеја у Београду бр. 74, 1971, 85-104.

MOS 1982: MOS, Marsel. „Ogled o daru“. Sociologija i antropologija II. Prev. Ana Moralić. Beograd: Prosveta, 1982, 7-222.

POPOVIĆ 2001: POPOVIĆ, Ljudmila. „O prototipskom i stereotipskom načinu konceptualizacije boja u jeziku“. Boje, Kodovi slovenskih kultura. Ur. Dejan Ajdačić. Beograd: Clio, 2001, 14-31. [orig.] Поповић, Људмила. „О прототипском и стереотиском начину концептуализације боја у језику.“ Боје, Кодови словенских култура. Ур. Дејан Ајдачић. Београд: Clio, 2001, 14-31.

RENKAS 2016: RENKAS, Joana. „Hrišćanska simbolika bosiljka u kontekstu teorije kulturne memorije religijskih grupa“. Gora ljiljanova, biljni svet u tradicionalnoj kulturi Srba. Ur. Z. Karanović i J. Dražić. Beograd: Udruženje folklorista Srbije i Univerzitetska biblioteka „Svetozar Markovićc, 2016, 41-56. [orig.] Ренкас, Јоана. „Хришћанска симболика босиљка у контексту теорије културне меморије религијских група“. Гора љиљанова, билни света у традиционалној култури Срба, ур. 3. Карановић и Ј. Дражић. Београд: Удружење фолклориста Србије и Универзитетска библиотека 
„Светозар Марковић“, 2016, 41-56.

SAVIĆ GRUJIĆ 2010: SAVIĆ GRUJIĆ, Ana. „Leksika u vezi sa hlebom u timočkom dijalekatskom rečniku Jakše Dinića“. Tradicionalna estetska kultura. Hleb. Prir. Dragan Žunić. Niš: Centar za naučna istraživanja SANU i Univerziteta u Nišu, 2010, 255-258. [orig.] Савић Грујић, Ана. „Лексика у вези са хлебом у тимочком дијалекатском речнику Јакше Динића“. Традииионална естетска култура. Хлеб. Прир. Драган Жунић. Ниш: Центар за научна истраживања САНУ и Универзитета у Нишу, 2010, 255-258.

SOFRIĆ 1912: SOFRIĆ, Pavle Niševljanin. Glavnije bilje u narodnom verovanju i pevanju kod Srba. Beograd: Štamparija „Sveti Sava“, 1912. [orig.] Софрић, Павле Нишевљанин. Главније биље у народном веровағу и певағу код Срба. Београд: Штампарија „Свети Сава“, 1912.

STANIĆ 2012: STANIĆ, Danijela. „Funkcija bjele boje u 'Srpskim narodnim pjesmama I' Vuka Stefanovića Karadžića. Književnost i jezik, 3-4, 2012, 281-296. [orig.] Станић, Данијела. „Функција бјеле боје у 'Српским народним пјесмама I' Вука Стефановића Караџића“. Кюижевност и језик, 3-4, 2012, 281-296.

STANOJEVIĆ 1929: STANOJEVIĆ, Marinko. „Svadbeni običaji u Timoku“. Zbornik priloga za poznavanje Timočke krajine, br. 1, Zaječar, 1929, 23-79. [orig.] Станојевић, Маринко. „Свадбени обичаји у Тимоку.“ Зборник прилога за познаване Тимочке крајине, бр. 1, Зајечар, 1929, 23-79.

STEPANOVIĆ 2015: STEPANOVIĆ, Željko. „Postverbali s osnovom (-)bor od kontinuanata psl. glagola - ${ }^{\star} b r a t i$ u srpskom jeziku”. Savremena proučavanja jezika i književnosti VI. Kragujevac: FILUM, 2015, 15-22. [orig.] Степановић, Жељко. „Поствербали с основом (-)бор од континуаната псл. глагола *BЬRATI у српском језику.“ Савремена проучавана језика и книжевности VI. Крагујевац: ФИЛУМ, 2015, 15-22.

STEFANOVIĆ 2014: STEFANOVIĆ, Mirjana, D. „Posvećujem ove strukove smilja, kovilja i čubra“. Bilje u tradicionalnoj kulturi Srba. Prir. Z. Karanović. Novi Sad: Filozofski fakultet, 63-70. [orig.] Стефановић, Мирјана, Д. „Посвећујем ове струкове смиља, ковиља и чубра.“ Биље у традиционалној култури Срба, прир. 3. Карановић. Нови Сад, Филозофски факултет, 63-70.

TARNER 1986: TARNER, Viktor. „Varijacije na temu liminalnosti“. Gradina X, 1986. [orig.] Тарнер, Виктор. „Варијације на тему лиминалности“. Градина X, 1986. 40-56.

TOLSTOJ 1995: TOLSTOJ, Nikita. „Sekundarna funkcija obrednog simbola“. Jezik slovenske kulture. Niš: Prosveta, 1995, 141-160. [orig.] Толстој, Никита. „Секундарна функција обредног симбола“. Језик словенске културе: Ниш: Просвета, 1995, 141-160.

TOPORKOV 2001: TOPORKOV, Andrej L. „Hleb“. Slovenska mitologija. Beograd: Zepter book world. Ur. Svetlana Tolstoj i Ljubinko Radenković, 2001, 562564. [orig.] Топорков, Андреј Л. „Хлеб“. Словенска митологија, Београд: Zepter book world. Ур. Светлана Толстој и Љубинко Раденковић, 2001, $562-564$. 
USAČEVA 1995: USAČEVA, Valerija V. „Bazilik“. Slavjanskije drevnosti. Etnolingvističeskij slovarı $v$ pjati tomah. Tom 1. Ur. N. I. Tolstogo. Moskva: Institut slavenovedenija RAN, 131-133. [orig.] Усачева, Валерия В. „Базилик“. Славянские древности. Этнолингвистический словарь в пяти томах Том 1, ур. Н. И. Толстого Москва: Институт славноведения РАН, 131133.

ČAJKANOVIĆ 1935: ČAJKANOVIĆ, Veselin. „Bosiljak“. Glasnik etnografskog muzeja u Beogradu, br. 10, 1935, 3-10. [orig.] Чајкановић, Веселин. „Босиљак.“ Гласник етнограбског музеја у Београду, бр. 10, 1935, 3-10.

ČAJKANOVIĆ 1994a: ČAJKANOVIĆ, Veselin. „Rečnik srpskih narodnih verovanja o biljkama“. Sabrana dela, knj. IV. Prir. V. Đurić. Beograd: SKZ, BIGZ, Prosveta, Partenon, 1994. [orig.] Чајкановић, Веселин. „Речник српских народних вероваюа о биљкама“. Сабрана дела, књ. IV. Прир. В. Ђурић, Београд: СКЗ, БИГЗ, Просвета, Партенон, 1994.

ČAJKANOVIĆ 1994b: ČAJKANOVIĆ, Veselin. „Religija i kult drveta i biljaka“. Stara srpska religija i mitologija, Sabrana dela, knj. V. Prir. V. Đurić. Beograd: SKZ, BIGZ, Prosveta, Partenon, 1994. 169-182. [orig.] Чајкановић, Веселин. „Религија и култ дрвета и биљака“. Стара српска религија и митологија, Сабрана дела, књ. V. Прир. В. Ђурић, Београд: СКЗ, БИГЗ, Просвета, Партенон, 1994, 169-182.

ŠORAK 2013: ŠORAK, Marija. „Sedenjka i sedenjkarske pesme u Dobriču“. Glasnik etnografskog muzeja, br. 77, 2013, 207-225. [orig.] Шорак, Марија. „Седењка и седењкарске песме у Добричу“. Гласник етногрфског музеја, бр. 77, 2013, 207-225.

\section{Извори}

RJAZU: Rječnik hrvatskoga ili srpskoga jezika JAZU I-XXIII, Zagreb 1880-1976.

ĐORĐEVIĆ i ZLATANOVIĆ 1990: ĐORĐEVIĆ, Dragutin i Momčilo Zlatanović. Narodne pesme iz Leskovačke oblasti. Beograd: SANU, 1990. [orig.] Ђорђевић, Драгутин и Момчило Златановић. Народне песме из Лесковачке области. Београд: САНУ, 1990.

JOCIĆ i JOCIĆ 1979: JOCIĆ, Života, Radomir Jocić, i dr. Đul devojče. Lirske narodne pesme iz belopalanačkog kraja. Niš: Gradiina, 1979. [orig.] Јоцић, Живота, Радомир Јоцић, и др. Ђул девојче. Лирске народне песме из белопаланачког краја. Ниш: Градина, 1979.

KARADŽIĆ 1852: KARADŽIĆ, Vuk Stefanović. Srpski rječnik istumačen njemačkim i latinskim riječima. Beč: Štamparija Jermenskog manastira, 1852. [orig.] Караџић, Вук Стефановић. Српски рјечник истумачен ғемачким и латинскијем ријечима. Беч: Штампарија Јерменског манастира, 1852.

MANOJLOVIĆ 1953: MANOJLOVIĆ, Kosta. Narodne melodije iz istočne Srbije. Beograd: SANU, 1953. [orig.] Манојловић, Коста. Народне мелодије из источне Србије. Београд: САНУ, 1953.

RAJKOVIĆ KOŽELJAC 1978: RAJKOVIĆ KOŽELJAC, Ljubiša. Zdravac mirišljavac. Zaječar: Grafičko izdavačko preduzeće „Zaječar“, 1978. [orig.] Рајковић 
Кожељац, Љубиша. Здравац мириштьваи. Зајечар: Графичко издавачко предузеће „Зајечар“, 1978.

STANOJEVIĆ 1903: STANOJEVIĆ, Marinko. „Nekoliko varijanata narodnih pesama sa Timoka“. Karadžić. List za srpski narodni život, običaje i predanje. Izdaje i uređuje Tihomir R. Đorđević, br. 2, IV, 1903, 96-108. [orig.] Станојевић, Маринко „Неколико варијаната народних песама са Тимока“. Караиић. Лист за српски народни живот, обичаје и предане. Издаје и уређује Тихомир Р. Ђорђевић. бр. 2, IV, 1903, 96-108.

Zoja S. Karanović

\section{SERBIAN WEDDING CUSTOMS RELATED TO THE RITUAL BREAD (ZBORNJAK) - FIELD RESERCH IN SOUTH EASTERN SERBIA}

The subject of research in this paper is a segment of wedding customs related to a rituals conected to a main wedding bread named zboranjak in South Easten region of Serbia near the river Beli Timok, where the author was on the field together with colleague Vesna Đukić (in 1997 and 1998). The word zboranjak, which is ethmologically related to gathering, completely corresponds to mentioned ritual object (wedding bread) and its functions, since during the wedding members of the community who participate in it gather around it, performing various actions and sing songs. In this region the wedding itself begins on Friday with kneading bread (by a neighbor invited by the hostess), and ends when the the bread is crushed after three days. Meanwhile, when the zbornjak is prepared, the girls from the village decorate it with flowers of basil, immortelle, amaranth... Then they put it on the table in front of the newlyweds, and later on bread is bestowed by wedding guests who get some flowers from it. After all, at the end of the wedding the bread is broken and a dish is made of it by steaming, and was tasted first by the newlyweds and then other young members of the community. After all, analyzes in this work have shown that the main function of this ritual bread is integrative - the actions around it confirm the unity of the group, which for a premodern traditional people is a condition of survival. And that is shown in the work.

Key words: field work, South Eastern Sebia, wedding ceremony, ritual bread, decoration by flovers, singing to the bread, giving money to the bread 